\title{
Mandatory Disclosure and Its Impact on the Company Value
}

\author{
Tatiana Popova ${ }^{1}$, Georgios Georgakopoulos ${ }^{1}$, Ioannis Sotiropoulos ${ }^{2}$ \& Konstantinos Z. Vasileiou ${ }^{3}$ \\ ${ }^{1}$ Amsterdam Business School - Accounting Group, University of Amsterdam, the Netherlands \\ ${ }^{2}$ Department of Finance and Auditing, Technological Educational Institute of Epirus, Greece \\ 3 Department of Business Planning \& Information Systems, Technological Educational Institute of Patras, \\ Greece
}

Correspondence: Konstantinos Z. Vasileiou, Department of Business Planning \& Information Systems, Technological Educational Institute of Patras, Greece. E-mail: vasileiou@teipat.gr

Received: February 13, 2013

Accepted: April 1, $2013 \quad$ Online Published: April 17, 2013

doi:10.5539/ibr.v6n5p1

URL: http://dx.doi.org/10.5539/ibr.v6n5p1

\begin{abstract}
This study investigated the association between mandatory disclosure and company value expressed in share price anticipation of earnings by using a sample of UK companies included in the FTSE 350 Index for a period of five years, from 2006 to 2010. A mandatory disclosure index was developed according to the IFRSs, which the companies listed in the stock market were obliged to adopt since 2005, and was utilized for the quantification of the extent of mandatory disclosure. The relationship between mandatory disclosure and some specific company characteristics was also investigated. The analysis revealed a high level of disclosure by UK companies indicating that managers do not treat mandatory disclosure as a routine obligation, but they strive to be strictly compliant with all reporting requirements imposed by the regulatory authorities. Moreover, the extent of disclosure was significantly correlated with company value, leverage and age, which justifies that market mechanism is also essential in disclosure practice. However, the correlation between mandatory disclosure and listing status, earnings and size is not statistically significant.
\end{abstract}

Keywords: mandatory disclosure, company value, IFRSs, leverage, age, earnings, size, listing status

\section{Introduction}

Cerf (1961) first investigated the corporate-specific attributes, which determined the level of disclosure, namely, he aimed to quantify qualitative information disclosed by companies in annual reports. This study triggered the attention of many researchers (Adina et al., 2008; Barako et al., 2006; Ahmed et al., 1994; Owusu-Ansah, 1998; Akhtaruddin, 2005; Belkaoui et al., 1978; Buzby, 1974; Cerf, 1961; Cooke, 1989; Omar et al., 2011 and others) as they empirically investigated the relationship between the level of disclosure and specific characteristics of companies. Since then disclosure has been explored through various theories, such as stakeholder theory, agency theory, political economy theory, and legitimacy theory (Choi, 1973). According to Cooke (1989), although different conclusions accrue from these different theories, there is a consensus that the information released by companies mostly targets financial analysts, creditors and investors, since this information is important for their decision- making regarding investments.

Disclosure is twofold: a) mandatory disclosure, when regulatory authorities impose on companies to disclose certain elements of information; and b) voluntary disclosure, when companies decide to disclose more information than required because they deem that this will benefit them. Managers should carefully plan their disclosure strategy as the benefits include improved reputation of the company in the market, less political and regulation intervention and enhanced stock liquidity (Entwistle, 1997).

Despite these evident benefits, there were still concerns about how proper the disclosure was, due to the reporting options available to managers, as they could follow either the local GAAP or the IFRSs proposed by IASB. The situation has changed since 2005 when IASB obliged listing companies from the member-states of the European Union to report under the IFRSs. IFRSs enhance the transparency of accounting numbers and reduce the scope for judgment and earnings manipulation (Iatridis, 2008).

Most of the research so far has focused on exploring the voluntary rather than the mandatory disclosure (Einhorn, 2005), despite the fact that both mandatory and voluntary disclosures are potentially important (Omar 
et al., 2011). Indeed, voluntary disclosure, among others, lowers the cost of capital, increases the company market value and reduces the asymmetry of information (Bruslerie et al., 2010). Several studied examined the relationship between share price anticipation of earnings and voluntary disclosure (Hussainey et al., 2003; 2009; Healy et al., 1999; Healy et al., 2001). These findings suggest that when companies voluntarily increase the extent of disclosure, the ability of stock market to predict the changes of future earnings is considerably improved. Given the significant interaction between mandatory and voluntary disclosure (Yu, 2011), this raises the question, "is there a link between mandatory disclosure and stock liquidity?" However, according to Healy et al. (2001) there is limited evidence on the economic consequences of mandatory disclosure and the findings from these studies do not provide a clear picture.

The aim of this study is to investigate the association between mandatory disclosure and company value expressed in share price anticipation of earnings, and the correlation between mandatory disclosure and some characteristics of companies like profitability, leverage, company age and size, listing status. The sample consisted of UK companies from the FTSE 350 Index for a period of five years, from 2006 to 2010 . The reason for selecting the UK companies is that they are subject to constant scrutiny and invigilation to a great extent (Iatridis, 2008). Therefore, the UK companies are known for their best practice in disclosing high quality information and long reporting history.

This study aims to investigate the impact of mandatory disclosure on company value. In this light, the next section presents the literature review regarding disclosure, motives for disclosure, measurement techniques, and salient factors of disclosure extent. Next, the hypotheses, the methodology and the sample of the study are reported. The research findings are presented afterwards, and the last section deals with conclusions, limitations and recommendations.

\section{Literature Review}

\subsection{Mandatory Disclosure, Voluntary Disclosure and Their Association}

Globalization and the awareness of potential investors about the published financial information have led to an increased demand and quality for that information. Disclosure is one of the tools that managers use to communicate information to investors. Mandatory disclosure is a responsibility of regulatory organizations (security exchange authorities, IASB, FASB, etc.), while voluntary disclosure is a responsibility of managers. Therefore, investors must be aware when mandatory disclosure is not relevant anymore and managers start employing voluntary disclosure "as managers are likely to consider their own interests when exercising managerial discretion" (Akhtaruddin, 2005).

Owusu-Ansah (1998) and Wallace et al. (1995) consider disclosure as a communication of economic information, whether financial or non-financial, quantitative or otherwise concerning a company's financial position and performance. Disclosure results in a combination of mandatory and voluntary items that constantly interact with each other. Mandatory disclosure is a company's obligation to disclose a minimum amount of information in corporate reports (Wallace et al., 1995; Owusu-Ansah, 1998), whereas voluntary disclosure is a provision of additional information when mandatory disclosure is unable to provide a true picture about company's value and managers' performance.

Mandatory disclosure is governed by regulatory agencies in all countries around the world (Healy et al., 2001; Akhtaruddin, 2005). Regulators force companies to disclose information that companies may wish to hide (Darrough, 1993). One of the explanations for disclosure regulation is the concern of the regulatory bodies to safeguard the welfare of ordinary investors (Watts \& Zimmerman, 1986; Taplin et al., 2002). Regulators aim to redistribute the wealth between informed and uniformed investors by requiring a minimum level of disclosure, as the information gap among them is expected to shorten (Healy et al., 1999). Furthermore, the credibility of the information in capital markets is positively influenced by the existence of disclosure regulation, which also ensures companies' compliance to the regulatory requirements (Al-Htaybat et al., 2006).

But sometimes mandatory disclosure may not be sufficient to address the expectations of investors. Thus, voluntary disclosure is used by managers to transfer to investors their best information of company's performance (Graham et al., 2005; Healy et al., 2001). Therefore, voluntary disclosure concerns the additional information, which depends on the company's discretion, the relevant legislation and the external pressures of the consulting firms, financial analysts, capital markets and the cultural factor.

Thus, mandatory and voluntary disclosures should not be considered as different items of financial reporting, as both are potentially important (Omar et al., 2011) and they interact with each other constantly (Yu, 2011). When mandatory requirements are limited or regulations are vague and difficult to interpret, companies have incentives 
to replace missing information with voluntary one. When regulators mandate voluntary information there is no need for company to create discretionary disclosure strategies (Einhorn, 2005).

Previous researchers have investigated the interaction between these two types of disclosure (Einhorn, 2005; Dye, 1985, 1986; Naser et al., 2003; Al-Razeen et al., 2004; Yu, 2011). Dye (1985; 1986) investigated the impact of mandatory requirements on voluntary disclosure in terms of proprietary costs and found that the effect is subject on whether the two types of disclosure are substitutes or complements. In case they are substitutes, an increase in the requirements of mandatory disclosure will result in lower voluntary disclosure, while the contrary will occur when they are complements. A significant and positive association between voluntary and mandatory disclosures was found by Naser et al. (2003), whereas Al-Razeen et al. (2004) found no clear association between these two disclosures. The potential explanation for that is a lack of cooperation between the board of directors and management.

In summary, there is no a clear association between these two concepts. Companies have to determine what optimal level of total disclosure is appropriate for them (Leuz at el., 2008). Either companies strictly follow the regulatory requirements and limit their discretion over voluntary disclosure, or they meet minimum mandatory requirements and extend their reporting by voluntary provision of information.

\subsection{Motives for Disclosure}

Voluntary disclosure is a means for managers to attract investors and other stakeholder groups' attention to their companies. Healy et al. (2001) identified five hypotheses that influence managers' disclosure decision-making for capital market reasons:

1) The capital market transaction hypothesis: Companies that make voluntary disclosure reduce information asymmetry and thus the reduced information risk decreases the cost of external financing;

2) The corporate control contest hypothesis: When the performance of companies is low, voluntary disclosure is useful for managers to explain the poor performance and improve the firm evaluation, and thus it is more probable to retain their jobs;

3) The stock compensation hypothesis: Voluntary disclosures are helpful both to managers rewarded with stock compensation to reduce the possibility of insider trading allegations, and to companies to decrease contracting costs with managers receiving stock compensation;

4) The litigation cost hypothesis: Managers communicate bad news to prevent legal actions against themselves, while they also reduce communications of future estimates that might prove to be incorrect; and

5) The proprietary costs hypothesis: Managers will decrease voluntary disclosures when they deem that these could be competitively harmful.

Beyer et al. (2010) mentioned that "justifying disclosure regulation is often quite challenging" and "there is no comprehensive theory of mandatory disclosure". The four main justifications for disclosure regulations are:

1) Financial externalities: they appear when a company discloses information not only about its own financial position, but as well about that of other companies. Since a company usually ignores information about other companies, the rival companies have incentive to decrease the provision of information. In this case, regulation is improving social welfare (Easterbrook et al., 1991; Admati et al., 2000).

2) Real externalities: they exist when a company's disclosure affects other companies' real decisions (e.g. about their production volume (Kanodia et al., 2000)). If disclosed information allows other companies to make more informed decisions, regulations mandating additional disclosure can improve social welfare.

3) Agency costs: regulators can enforce disclosure when investors are powerless and they could not force managers to comprehensively disclose information about their financial position. This also increases social welfare (Beyer et al., 2010).

4) Economies of scale: common accounting standards are beneficial since they improve the comparability of disclosures across firms and they decrease investors' effort to gather information. Thus, it is more probable to reach to accurate estimates of the performance of various firms (Dye et al., 2001) and achieve economies of scale in terms of interpreting disclosures for investors (Dye et al., 2008; Mahoney, 1995).

\subsection{Measurement of Disclosure}

Disclosure is often qualitative and narrative in nature, thus it is difficult to measure it in an objective manner (Leuz at el., 2008). There is still little guidance of what may be considered as relevant and of high-quality disclosure for investors. IASB provides description of what is high-quality information that may have meaning 
for investors (see "Qualitative characteristics of useful financial information" of Conceptual Framework). Wallace et al. (1995) identified five key aspects of "quality" for disclosure: readable, timely, understandable, adequate for a defined purpose, comprehensive and informative. But the practical application of these qualitative characteristics still imposes challenges for researchers.

A common practice to measure disclosure is based on experts' perceptions of what is useful and important for investors. Lang et al. (1993), Healy et al. (1999) and Nagar et al. (2003) utilized the expertise of different groups of financial analysts in ratings development. But, the rankings may be biased, depending on the objectives of sell-side analysts. Other researchers measure disclosure using self-constructed check-lists (Aljifri (2008), Bruslerie et al. (2010), Cooke (1989), Cerf (1961), Omar et al. (2011) and others). These types of measures have limitations such as: a) researchers generally capture the existence of particular disclosures, rather than their quality, b) the construction of a single index requires the assignment of particular weights to the different disclosure items and c) the selection and coding of the relevant disclosures is subjective. Thus, there is clearly a need for more research to improve existing tools as well as to capture qualitative and narrative disclosures more broadly (Core, 2001).

\subsection{Company Specific Characteristics}

There are many external and internal factors that potentially influence disclosure practice. Investigating these factors and their relationship with the extent of disclosure not only enhances the understanding of the reasons behind the variation in disclosure, but it may also help policy makers to choose the best measures to mitigate imperfections (Cooke, 1989).

Haniffa et al. (2002) argued that there are five groups of factors that affect disclosure practice: enforcement mechanisms, capital markets, accounting and regulatory framework, economy, and culture. The association between the disclosure level and specific company characteristics (e.g. company size, leverage, listing status, profitability, ownership structure, audit firm size, industry type, etc.) is investigated by many researchers (Gray et al., 1995; Healy et al., 2001; Cooke, 1989; Wallace et al., 1995; Owusu-Ansah, 1998; Lang et al., 1993; Hossain et al. 1994).

It is also rather interesting to evaluate the relationship of the level of disclosure with stock liquidity. There is a general prediction that voluntary disclosure decreases the gap of information asymmetries among informed and uninformed investors (Healy et al., 1999). Consequently, investors of companies with higher level of disclosure have more confidence about the fair value of company, and this benefits the company by increasing its liquidity of stocks unrelated to current earnings performance (Healy et al., 1999). Hussainey et al. (2009) revealed that share price anticipation of earnings is improved by increasing the level of disclosure of annual report narratives, because they are more likely to contain forward-looking earnings prediction. Graham et al. (2005) found that companies voluntarily disclose information to facilitate the clarity and understanding of investors. Managers believe that the non-provision of accurate and precise information with clear narratives leads to under-valuation of companies' stock. On the other hand, in the absence of the disclosure, investors appreciate the company value by a weighted average of the narratives of annual reports (Beyer et al., 2010). Although, the link between disclosure and stock price liquidity has been specified, most of the prior research literature concentrated on voluntary disclosure, while mandatory disclosure attracted very little attention (Einhorn, 2005).

\section{Research Hypotheses}

This research aims to investigate the impact of mandatory disclosure on the company value and, specifically, on the level of share price anticipation of earnings. Prior literature suggests that there is a link between voluntary disclosure and share price response, as managers that posses "good news", due to better performance, are more likely to disclose more detailed information to the capital market than that provided by "bad news" companies to avoid under-valuation of their shares (Inchausti, 1997). On the other hand, managers treat mandatory disclosure as a routine or an obligation imposed on them by regulatory organizations to provide minimum amount of information (Owusu-Ansah, 1998; Wallace et al., 1995). Voluntary and mandatory disclosure are found to be interdependent (Einhorn, 2005; Omar et al., 2011; Naser et al., 2003; Yu, 2011), and consequently it is expected that not only voluntary disclosure is associated with share price response but this is also the case for mandatory disclosure. Thus, the first research hypothesis is:

Hypothesis 1: Higher firm value, expressing by the level of share price anticipation of earnings, is positively associated with higher level of mandatory disclosure.

Prior research suggests that control variables such as profitability, size, leverage, age, and listing status are related with the level of disclosure (e.g. Yu, 2011; Hussainey et al., 2009; Bruslerie et al., 2010; Akhtaruddin, 
2005; Hossain et al., 2009).

Earnings are the annual net income before extraordinary items are scaled by market value. There is a general perception that companies disclose more information during periods of increased earnings and less when earnings decline (Yu, 2011). Moreover, agency theory suggests that managers of larger profitable companies may wish to disclose more information to obtain personal advantages like continuance of their management position and compensation (Inhausti, 1997). Belkaoui et al. (1978) also examined the relationship between earnings and the level of disclosure, and they found a negative association between these two variables whereas the majority of other researches mentioned a positive association. A negative relationship may be attributed to the fact that unprofitable companies will also be inclined to release more information in order to justify their poor performance (Owusu-Ansah, 1998). Indeed, Lang et al. (1993) and Wallace et al (1994) mentioned that the impact of a company's profitability on the extent of disclosure can be positive (Singhvi, 1968; Singhvi et al., 1971; Courtis, 1979; Owusu-Ansah, 1998), neutral (McNally et al., 1982; Lau, 1992) or negative (Wallace et al., 1995) depending on its performance.

Hypothesis 2a: Earnings are positively associated with higher level of mandatory disclosure.

Another control variable is Leverage. It is company's total liabilities divided by total assets. Chow et al. (1987) and Ahmed et al. (1994) found no significant correlation between leverage ratio and the extent of voluntary disclosure, whereas Robbins et al. (1986), Karim et al. (2005), Bruslerie et al. (2010) and Omar et al. (2011) found a significant positive association. In general, it is deemed that a highly leverage company should provide more details in annual report in order to mitigate long-term creditors' concerns about potential defaults and to avoid agency costs (Omar et al., 2011; Wallace et al., 1994).

\section{Hypothesis 2b: Leverage is positively associated with higher level of mandatory disclosure.}

Company age is a critical factor in determining the level of corporate disclosure. Older companies with more experience are likely to include more information in their annual reports in order to enhance their reputation and image in the market. According to Owusu-Ansah (1998) the main reasons are: a) younger companies may suffer from a competitive disadvantage and, thus, they disclose information with some caution, b) the cost of gathering, processing, and disseminating the required information may be a burden for younger companies, and c) younger companies may lack a "track record" to rely on for public disclosure, in case of being established by merger and acquisition, and there is simply no information to disclose.

There are several ways to distinguish mature from younger companies. For example, mature companies get most of their value from existing assets, whereas younger companies derive a significant proportion of their value from growth assets (Damodaran, 2009). Berk et al. (2011) reported that firms with high R\&D costs and future growth opportunities typically maintain low debt levels (approximately less than 10\% leverage). Mature, low-growth firms with stable cash flows and tangible assets often fall into the high-debt category (approximately greater than $20 \%$ leverage). In this study, for the Age dummy variable firms are divided in two groups with greater than 20\% leverage (mature equals one) and less than $20 \%$ leverage (younger equals zero).

Hypothesis 2c: Company Age is positively associated with higher level of mandatory disclosure.

Cerf (1961), Buzby (1974), and more recently Cooke (1989) found positive relationship between firm size and the extent of disclosure. Larger companies may tend to disclose more information than smaller companies in their annual reports due to their competitive cost advantage (Lobo at el., 2001). It is easy and less-time consuming for larger companies to produce and publish more sophisticated financial statements, exhibit more disclosure compliance and greater level of disclosure (Ahmed at el., 1994) due to the possession of the necessary resources and expertise comparing to smaller ones. Size is a sign of growth of company (Wallace et al., 1995) and it is obvious that a growing company requires more external capital and, consequently, more comprehensive information is published to obtain capital at lower cost. Another argument for the positive association between size and disclosure level is that a great number of analysts peruse large companies resulting in a greater demand for information (McKinnon et al., 1993). The proxy for the firm size (Size) is calculated as a natural logarithm of market value, where market value is the number of shares outstanding multiplied by the stock price as of the date of issue of annual report.

\section{Hypothesis 2d: Company Size is positively associated with higher level of mandatory disclosure.}

Companies listed in any stock market have to comply with listing rules, which are often strict and require extra disclosure in annual reports. As a result, the level of detail in annual reports and accounts may vary between listed and unlisted companies (Wallace et al., 1994). Omar et al. (2011) mentioned that the association between aggregate disclosure (both voluntary and mandatory) and listed companies is significantly higher than that for 
companies not listed. Hence, the association between listing status (Listing) and disclosure level is expected to be positive. However, the sample of this study consists of companies listed in FTSE 350 Index, namely in both FTSE 250 and 100 Indexes. Although, no great differences are expected between these two groups of companies, Listing is incorporated in the analysis as a dummy variable, where zero is assigned to a company listed in FTSE 250 Index and one when listed in FTSE 100 Index.

Hypothesis 2e: Listing status is positively associated with higher level of mandatory disclosure.

\section{Methodology and Data Collection}

\subsection{Construction of the Disclosure Index}

Since the seminal work of Cerf (1961), several other attempts were made to develop disclosure index and measure qualitative information (Buzby, 1974; Cooke, 1989; Akhtaruddin, 2005; Aljifri, 2008; Hossain et al., 2009; Bruslerie et al., 2010). The degree of subjectivity in these studies is varying depending on the knowledge and experience of the researchers who built and measured the index. However, there is still no consensus on the best practice that would help measuring the extent of voluntary and mandatory disclosure, defining the quality of items and determining which items impact most on the company value (Marston et al., 1991).

Disclosure, by its nature, is an abstract construct (Wallace et al., 1995), which lacks of stable inherent characteristics that can determine its quality. Moreover, disclosure is constantly updated by new regulations. Therefore, using the items included in the previous similar studies mentioned above would not allow to capturing all disclosure requirements under the new legislation. Furthermore, Cooke (1989), Barako et al. (2006), Bruslerie et al. (2010), Buzby (1974), Hossain et al. (2009) and Hussainey et al. (2009) focused on the voluntary disclosure, whereas this study concentrates on mandatory disclosure.

Although, there are several ways of communicating company information, such as press releases, interim reporting and others, annual report is still considered the major medium disclosing information, as it is easily available and accessible (Bruslerie et al., 2010). However, data collection is limited by the notes to the financial statements, which contain narrative description of additional items to those presented in the financial statements and information about items that do not qualify for recognition in those statements.

In order to formulate the index, mandatory disclosure items were collected from the IFRSs. Each standard contains a section named Disclosure with a list of items required to be disclosed in an annual report by a company. Some items are optional and their inclusion depends on the accounting policy of the company. In this study all items were included in the disclosure index resulting in the list of mandatory and optional (i.e. a mandatory item not relevant to a company due to its nature of conducting business) items.

The following standards were omitted at the construction of index: IAS 34 "Interim Financial Reporting" because this study focuses on one year period and not on the half of the year; IAS 41 "Agriculture" since there are no companies from the agriculture sector in the FTSE 350 Index (Table 1); IFRS 1 "First-time Adoption of International Financial Reporting Standards" due to the fact the first year to be examined is 2006 and IFRS 1 has its specific requirements only for the first year of adoption (here and after 2005), which are no longer valid for subsequent years; IAS 29 "Financial Reporting in Hyperinflationary Economies" given that this standard shall be applied to the financial statements of companies whose functional currency is the currency of a hyperinflationary economy and no company was detected to meet that condition; IFRS 4 "Insurance Contracts" because no selected company has applied this standard in its accounting policy and the standard per se is extensively used by financial institutions that are not in the selection set of this study.

The following three standards IAS 39 "Financial Instruments: Recognition and Measurement", IAS 32 "Financial Instruments: Presentation", IFRS 9 "Financial Instruments" were excluded due to the fact that in August 2005 IASB amended these standards by relocating all disclosures relating to financial instruments to IFRS 7 "Financial Instruments: Disclosures". After investigating all standards a list of 290 optional and mandatory items was selected.

\subsection{Scoring the Disclosure Items}

There are two ways to evaluate the level of corporate disclosure: weighted and unweighted (Cooke, 1989). The advocates of the weighted approach (Copeland et al., 1968; Courtis, 1978; Barrett, 1977) consider that all items of information have different importance and some professional judgment is required to determine the weight. Such an approach leads to a scale of disclosure item, which varies from zero to one. However, the allocation of scores along the continuum is somewhat subjective (Cooke, 1989), as each group of users assigns different weights to a disclosure item than others depending on their knowledge and expertise. Thus, in order to conduct an analysis independent of the perception of a particular user group, the unweighted approach is employed 
(Chow et al., 1987).

This approach, which is also adopted in our study, is based on the assumption that each item is equally important for different group of stakeholders. This approach has also been employed in several prior studies (Cooke, 1989; Akhtaruddin, 2005; Bruslerie et al., 2010, Wallace et al., 1994, Omar et al., 2011). The assignment of score is based on a dichotomous basis - score one is given to an item being disclosed in the notes of the financial statement and zero score otherwise. Consequently, the final disclosure score for a company is addictive (Cooke, 1989).

The unweighted index is defined as the ratio of the number of items with the score one divided by the total disclosure (TD) score derived from the following equation:

$$
T D=\sum_{i=1}^{n} d_{i}
$$

Where, $d_{i}$ is the disclosed item with score of one or zero, and $n$ is number of items.

However, one main problem of the unweighted approach is that a company may be penalized by assigning a score of zero for the absence of a disclosure item not applicable to it. Therefore, it is important to explore the reason for not disclosing an item, because either this is not applicable for that particular company (so-called optional item) or the company chose to do so for its own purposes (Omar et al., 2011). For companies with optional items, the use of a relative index is suggested (Owusu-Ansah, 1998; Akhtaruddin, 2005; Cooke, 1989; Wallace et al., 1994), which is defined as the ratio of what a particular company actually disclosed divided by what the company is expected to disclose (Aljifri, 2008).

$$
T I=\frac{T D}{M}=\frac{\sum_{1}^{m} d_{i}}{\sum_{1}^{n} d_{i}}
$$

Where:

$T I=$ Total Disclosure Index

$T D=$ Total Disclosure Score

$M=$ Maximum disclosure score for each company

$d=$ Disclosure item $i$

$m=$ Actual number of relevant disclosure items $(\mathrm{m} \leq \mathrm{n})$

$n=$ Number of items expected to be disclosed.

This approach allows constructing a more accurate measure to score the disclosure items and the company is not penalized unreasonably.

\subsection{Regression Model}

In order to assess the impact of each variable on the mandatory disclosure level, a cross-sectional time-series regression analysis was applied based on the model proposed by Cooke (1989), Owusu-Ansah (1998), Omar et al. (2011), Hossain et al (2009) and etc.

The main difference between the model of this study and the above mentioned studies is the incorporation of the finding of Healy et al. $(1999 ; 2001)$ that firms with improved voluntary disclosure ratings attain a significantly improved share price performance in the year following the rating increase, compared to other firms in the same industry. In this study the improved share price performance is an independent variable and its relationship with mandatory level of disclosure is investigated. Furthermore, some of the control variables employed in the above mentioned studies are omitted as they are considered to be irrelevant.

The regression formula employed to test the research hypotheses is:

$$
\text { Index }_{i t}=\beta_{0}+\beta_{1} x \text { Return }_{i t}+\beta_{2} x \text { Earnings }+\beta_{3} x \text { Leverage }+\beta_{4} x \text { Age }+\beta_{5} x \text { Size }+\beta_{6} x \text { Listing }+\varepsilon
$$

The dependent variable is the individual index $\left(\right.$ Index $_{i t}$ ) of firm $i$ for the fiscal year $t$ measured by Equation 2 .

The key independent variable is stock return $\left(\right.$ Return $\left._{i t}\right)$, a primary measure of performance of firm $i$ for fiscal year $t$. Stock return value considered is that of the date of issue of annual reports (approximately 3 months after the end of the fiscal year of each company) in order to capture the initial reaction of investors. In this study, stock return is defined as a ratio (percentage) of the total return from dividends and capital gains, divided by the initial stock price (Berk et al., 2011): 


$$
R_{t+1}=\frac{D i v_{t+1}+P_{t+1}}{P_{t}}-1
$$

Where:

$\mathrm{R}_{\mathrm{t}+1}=$ Total return

$\operatorname{Div}_{\mathrm{t}+1}=$ Amount of dividend on date $t+1$

$\mathrm{P}_{\mathrm{t}}=$ Price of the stock on date $t$

$\mathrm{P}_{\mathrm{t}+1}=$ Price of the stock on date $t+1$.

\subsection{Sample of the Study}

Primary data were collected through archival research from companies' annual reports. As mentioned before, the sample of this study consists of companies included in the UK "FTSE 350 Index". The main reason is that UK companies are subject to constant scrutiny and invigilation to a great extent, thus they are known for their best practice in disclosing high quality information and long reporting history (Iatridis, 2008).

The FTSE 350 Index is a market capitalization weighted stock market index incorporating the largest 350 companies based on their capitalization, which they have their primary listing on the London Stock Exchange. It is a combination of the FTSE 100 Index of the largest 100 companies and the FTSE 250 Index of the next largest 250 companies. Financial institutions were excluded from the sample as they have specific requirements under the IFRSs not comparable to the companies from other industries. The final sample consists of 20 companies, selected randomly in order to avoid bias (Table 1), and thus, 100 observations were gathered during the five-year period of 2006-2010 studied.

Table 1. Sector representation in the sample

\begin{tabular}{|c|c|c|}
\hline \multirow[b]{2}{*}{ Sector } & \multicolumn{2}{|c|}{ Number of companies } \\
\hline & Total available & Selected \\
\hline Mining & 24 & 2 \\
\hline General retailers & 16 & 2 \\
\hline Oil\& Gas producers & 16 & 2 \\
\hline Media & 14 & 2 \\
\hline Aerospace \& Defense & 8 & 1 \\
\hline Household Goods \& Home Construction & 8 & 1 \\
\hline Industrial Engineering & 7 & 1 \\
\hline Oil Equipment \& Services & 7 & 1 \\
\hline Chemicals & 6 & 1 \\
\hline Food \& Drug Retailers & 6 & 1 \\
\hline Food Producers & 6 & 1 \\
\hline Gas, Water and Multiutilities & 6 & 1 \\
\hline Industrial Metal \& Mining & 3 & 1 \\
\hline Personal Goods & 3 & 1 \\
\hline Electricity & 2 & 1 \\
\hline Automobiles \& Parts & 1 & 1 \\
\hline Support Services & 32 & 0 \\
\hline Travel \& Leisure & 23 & 0 \\
\hline Software \& Computer Services & 10 & 0 \\
\hline Fixed Line Telecommunications & 7 & 0 \\
\hline Electronic \& Electrical equipment & 6 & 0 \\
\hline Pharmaceuticals \& Biotechnology & 6 & 0 \\
\hline General industries & 5 & 0 \\
\hline Technology Hardware \& Equipment & 5 & 0 \\
\hline Beverages & 4 & 0 \\
\hline Construction \& Materials & 4 & 0 \\
\hline Health Care Equipment \& Services & 2 & 0 \\
\hline Industrial Transportation & 2 & 0 \\
\hline Mobile Telecommunications & 2 & 0 \\
\hline Tobacco & 2 & 0 \\
\hline Forestry\& Paper & 1 & 0 \\
\hline Financial institutions & 106 & 0 \\
\hline Total & 350 & 20 \\
\hline
\end{tabular}


Officially, 2005 is the first year when listing companies were obliged to produce financial statements under the IFRSs. But some companies utilized the exemptions allowed under IFRS 1 "First Time Adoption of International Financial Reporting Standards". Since this could jeopardize the comparability among companies, the construction of the disclosure index and its scoring, 2006 was selected as the first year to be examined. 2011 was excluded from the analysis because several companies have different year end (e.g. in June or in September), therefore, there was a lack of financial information for these companies for 2011 when conducting the research.

The only variable, which is not available in the annual reports, is Return. Stock prices required to perform the calculations were collected from publicly available sources (either from Yahoo!Finance or company website).

\section{Research Results}

\subsection{Descriptive Statistics}

Table 2 summarizes the descriptive statistics for the variables used in the study. Panel A reports dependent variable per year and Panel B reports all variables for the five-year period. The average mandatory disclosure index for the five-year period is $91.51 \%$ (with minimum $69.31 \%$ and maximum $100 \%$ ), which is consistent with the disclosure indexes reported by Wallace et al. (1995) in Hong Kong (mean 72.54\%), Owusu-Ansah (1998) in Zimbabwe (mean 74.43\%) and Omar et al. (2011) in Jordan (mean 83.12\%). However, the disclosure index of this study is a bit higher than that of the previous ones, which can be attributed to the high-quality disclosure practice of the UK listing companies compared with that of other countries.

Panel A indicates a gradual progress of disclosure index during the studied five year period. 2006 is the year with the lowest disclosure index (mean 87.82\%), but it is still higher compared to the above mentioned studies, probably because this year was only the second year after the adoption of the IFRSs in the EU and the companies had not gained sufficient experience how to report properly under the IFRSs.

According to Panel B there is a broad range of variation in leverage and size. Leverage ranges from 0.1386 to 0.9714 with a mean of 0.6084 and standard deviation of 0.1671 , and size ranges from 4.5116 to 10.1533 with mean 7.8750 and standard deviation 1.2511. The size distribution is skewed. Skewness is mitigated by utilizing natural logarithm of size in the regression analysis, consistent with prior studies (Hossain et al., 2009). On the contrary, return and earnings are consistent to each other. Return ranges from -0.8657 to 3.5360 with a mean of 0.1644 and a standard deviation of 0.7031 , and earnings range from -0.8636 to 3.0245 with a mean of 0.1185 and a standard deviation of 0.3925 .

Table 2. Summary statistics (number of observations 100)

\begin{tabular}{|c|c|c|c|c|}
\hline \multicolumn{5}{|c|}{ Panel A: Descriptive statistics for dependent variable Disclosure index } \\
\hline Year & Mean & Standard deviation & Min & Max \\
\hline 2006 & 0.8782 & 0.0655 & 0.6931 & 0.9688 \\
\hline 2007 & 0.9015 & 0.0578 & 0.7273 & 0.9762 \\
\hline 2008 & 0.9256 & 0.0535 & 0.7358 & 0.9883 \\
\hline 2009 & 0.9342 & 0.0578 & 0.7327 & 1.0000 \\
\hline 2010 & 0.9358 & 0.0523 & 0.7619 & 1.0000 \\
\hline \multicolumn{5}{|c|}{ Panel B: Descriptive statistics for all variables for five-year period } \\
\hline Variable & Mean & Standard deviation & Min & Max \\
\hline Disclosure index & 0.9151 & 0.0606 & 0.6931 & 1.0000 \\
\hline Return & 0.1644 & 0.7031 & -0.8657 & 3.5360 \\
\hline Earnings & 0.1185 & 0.3925 & -0.8636 & 3.0245 \\
\hline Leverage & 0.6084 & 0.1671 & 0.1386 & 0.9714 \\
\hline Age & 0.9900 & 0.1000 & 0.0000 & 1.0000 \\
\hline Size & 7.8760 & 1.2511 & 4.5116 & 10.1533 \\
\hline Listing & 0.5000 & 0.5025 & 0.0000 & 1.0000 \\
\hline \multicolumn{5}{|c|}{ Panel C: Descriptive statistics per Listing status } \\
\hline \multicolumn{5}{|c|}{ Number of observations: FTSE 100 - 50; FTSE 250 - 50} \\
\hline \multicolumn{5}{|c|}{ Disclosure index } \\
\hline Listing status & Mean & Standard deviation & Min & Max \\
\hline FTSE 250 & 0.9072 & 0.9244 & 0.6931 & 1.0000 \\
\hline FTSE 100 & 0.9230 & 0.9221 & 0.8298 & 1.0000 \\
\hline
\end{tabular}




\subsection{Correlation (Univariate) Analysis Results}

The Pearson product-moment correlation matrix of the dependent and independent variables is presented in Table 3. The Pearson correlation coefficients between disclosure index and age and leverage are higher, and significant at 5\% level, than the correlation coefficients between disclosure index and every other independent variable. This suggests that age and leverage captured phenomena may be different from those other variables could be impounding and collinearity among age and leverage may be an issue, while collinearity across the other variables is not. Leverage and age are also significantly correlated to each other (0.2839). Other statistically significant but lower coefficients are found between leverage and size (0.3405), and listing status and size (0.6424). These significant correlations suggest that multicollinearity may be a problem. One way to cope with these highly-correlated variables is to drop one or two of them from the regression equations (Wallace et al., 1995). A robustness test is performed in the subsequent section.

Table 3. Pearson correlation matrix

\begin{tabular}{|c|c|c|c|c|c|c|c|}
\hline Variable & Score $(\mathrm{TI})$ & Return & Earnings & Leverage & Age & Size & Listing \\
\hline Score (TI) & 1.0000 & & & & & & \\
\hline \multirow[t]{2}{*}{ Return } & $0.1581^{*}$ & 1.0000 & & & & & \\
\hline & 0.1163 & & & & & & \\
\hline \multirow[t]{2}{*}{ Earnings } & -0.0794 & 0.0387 & 1.0000 & & & & \\
\hline & 0.4322 & 0.7025 & & & & & \\
\hline \multirow[t]{2}{*}{ Leverage } & $0.1988 * *$ & $0.2238 * *$ & -0.0613 & 1.0000 & & & \\
\hline & 0.0474 & 0.0252 & 0.5445 & & & & \\
\hline \multirow[t]{2}{*}{ Age } & $0.2552 * * *$ & 0.1359 & 0.0170 & $0.2839 * * *$ & 1.0000 & & \\
\hline & 0.0104 & 0.1778 & 0.8669 & 0.0042 & & & \\
\hline \multirow[t]{2}{*}{ Size } & 0.1014 & -0.0443 & -0.0188 & $0.3405 * * *$ & 0.1003 & 1.0000 & \\
\hline & 0.3153 & 0.6615 & 0.8525 & 0.0005 & 0.3208 & & \\
\hline \multirow[t]{2}{*}{ Listing } & 0.1311 & 0.0472 & -0.0707 & $0.1528 *$ & 0.1005 & $0.6424 * * *$ & 1.0000 \\
\hline & 0.1935 & 0.6411 & 0.4844 & 0.1291 & 0.3198 & 0.0000 & \\
\hline
\end{tabular}

Notes: * Significant at $\mathrm{p}<0.1 ; * *$ Significant at $\mathrm{p}<0.05 ; * * *$ Significant at $\mathrm{p}<0.01$.

According to Healy et al. (1999) the disclosure rating is positively associated with stock return, which is also the case in this study ( 0.1581 significant at $10 \%$ level) and thus, hypothesis 1 is supported. The relationship between earnings and extent of mandatory disclosure was found negative and insignificant (-0.0794), which corresponds to the results from the studies of Wallace et al. (1995), Belkaoui et al. (1978), Aljifri (2008) and others. As mentioned above, this is probably due to the fact that unprofitable companies will release more information trying to explain their poor performance in order not to be penalized. Thus, hypothesis $2 \mathrm{a}$ is not supported.

There is also a significant positive association between leverage and the extent of mandatory disclosure (0.1988). The results support hypothesis $2 b$ and the perspective of agency theory that higher leverage companies disclose more information in order to avoid agency costs (Omar et al., 2011) or assuage investors' concerns about their financial conditions (Wallace et al., 1994; Iatridis, 2008; Inchausti, 1997). The results are consistent with those of prior studies (Wallace et al., 1994; 1995; Iatridis, 2008; Yu, 2011 and others). Furthermore, positive and significant correlation was also found between age and the extent of mandatory disclosure (0.2552), as it was indicated in prior studies by Owusu-Ansah (1998), and thus hypothesis 2c is supported. This can be explained by the so-called learning curve (Owusu-Ansah, 1998), when mature companies get used to mandatory disclosure requirements and consequently, the disclosure index increases over time.

The analysis revealed a positive association between size and the extent of mandatory disclosure (0.1014), which is consistent with the studies of Cerf (1961), Buzby (1974), Cooke (1989), Omar et al. (2011) and others, but statistically insignificant. The general rule is that large firms achieve greater economies of scale regarding information disclosure than small firms (Omar et al., 2011). In line with Cooke (1989), Wallace et al. (1994) and Omar et al. (2011) the listing status was found to be positively correlated with the extent of disclosure (0.1311), but statistically insignificantly. Panel $\mathrm{C}$ of Table 2 reveals that the mean of mandatory disclosure for companies listed in FTSE 100 Index is higher than that of companies listed in FTSE 250 Index (0.9230 against 0.9072 respectively). Thus, companies listed in FTSE 100 Index are more compliant to the IFRSs requirements. Thus, hypotheses $2 \mathrm{~d}$ and $2 \mathrm{e}$ are partially supported. 


\subsection{Regression (Multivariate) Analysis Results}

Table 4 presents the results of OLS regression model for all variables in order to assess the impact of each variable on the mandatory disclosure. The multiple regression model is statistically significant. The adjusted $\mathrm{R}^{2}$ indicates that $6.57 \%$ of the variation of the dependent variable is explained by the variations of the independent variables.

Table 4. OLS regression results

\begin{tabular}{|c|c|c|c|c|c|}
\hline \multicolumn{6}{|c|}{ Index $_{\mathrm{it}}=\beta_{0}+\beta_{1} \times$ Return $_{\mathrm{it}}+\beta_{2} \times$ Earnings $+\beta_{3} \times$ Leverage $+\beta_{4} \times$ Age $+\beta_{5} \times$ Size $+\beta_{6} \times$ Listing $+\varepsilon$} \\
\hline Variable & Expected sign & $\beta$ & t-statistics & $\mathrm{p}$-value & VIF \\
\hline Constant & & 0,7747 & 10,7500 & $0,0000^{* *}$ & \\
\hline Return & + & 0,0148 & 1,6700 & $0,0980 *$ & 1,1100 \\
\hline Earnings & $?$ & $-0,0111$ & $-0,7400$ & 0,4630 & 1,0100 \\
\hline Leverage & + & 0,0649 & 1,6000 & $0,1140^{*}$ & 1,3300 \\
\hline Age & + & 0,1068 & 1,6900 & $0,0940 *$ & 1,1500 \\
\hline Size & + & $-0,0015$ & $-0,2300$ & 0,8220 & 1,9100 \\
\hline Listing status & + & 0,0111 & 0,7200 & 0,4740 & 1,7500 \\
\hline \multicolumn{6}{|l|}{ Model summary } \\
\hline Number of observations & & 100 & & & \\
\hline $\mathrm{R}^{2}$ & & 0,1223 & & & \\
\hline Adjusted $\mathrm{R}^{2}$ & & 0,0657 & & & \\
\hline $\mathrm{F}$-value & & 2,1600 & & & \\
\hline $\mathrm{p}$-value & & $0,0538 * *$ & & & \\
\hline Mean VIF & & 1,3800 & & & \\
\hline
\end{tabular}

Notes: * Significant at $\mathrm{p}<0.1 ; * *$ Significant at $\mathrm{p}<0.05$; Table 2 defines the variables.

The coefficients of return, leverage and age are positive and statistically significant, between $5 \%$ and $10 \%$ levels, which support the relevant hypotheses. The coefficients for earnings (Hossain et al., 2009; Aljifri, 2008; Belkaoui et al., 1978, Spero, 1979), size (Aljifri, 2008; Spero, 1979; Akhtaruddin, 2005), and listing status (Omar et al., 2011) are insignificant and in line with the expected signs except for size. Given that the correlation analysis revealed a positive relationship between company size and the extent of mandatory disclosure, the negative relationship found by the regression analysis may be attributed to the multicollinearity effect with other independent variables. In order to address this issue a robustness test was performed (Table 5).

The Pearson correlation matrix revealed several significant correlations between the independent variables which indicate the potential existence of multicollinearity. Although none of the correlation coefficients verges to one, the correlation coefficients between leverage and age, size and leverage, and listing status and size are remarkably high compared with those between other variables. Table 4 reports that VIF for the independent variables are less than 10, suggesting that there is no multicollinearity between these variables (Aljifri, 2008). Despite this, contradictory results could occur, since the effect of multicollinearity (even though it is minor) still exists. In order to estimate the effect of multicollinearity, the regression model was modified and several regression models were employed (Table 5).

Model A (leverage and age excluded) yields significantly poor results. The adjusted $\mathrm{R}^{2}$ is only and moreover, this model is statistically insignificant. Therefore, leverage and age should not be omitted from the regression model. The results from both Model B (leverage and size omitted) and Model C (size and listing status omitted) are in line with the initial multiple regression model and they support hypothesis 1 . However, Model C yields the best results, as it is statistically significant and adjusted $\mathrm{R}^{2}$ equals to $7.94 \%$, which means that the significant correlation between size and listing status negatively affects the outcome.

Overall, it could be concluded that the extent of mandatory disclosure and share price anticipation of earnings are positively associated with each other indicating that managers should not treat mandatory disclosure as a routine obligation, but they should strictly comply with all disclosure requirements imposed by IASB. 
Table 5. Multiple regression results - Robustness test (number of observations 100)

\begin{tabular}{|c|c|c|c|c|c|c|c|}
\hline Model & Variable & $\beta$ & $t$-statistics & $p$-value & Adjusted $\mathrm{R}^{2}$ & $F$-value & $\mathrm{p}$-value \\
\hline \multirow[t]{6}{*}{ A } & Return & 0,0138 & 1,5800 & 0,1170 & 0,0078 & 1,1900 & 0,3188 \\
\hline & Earnings & $-0,0121$ & $-0,7800$ & 0,4360 & & & \\
\hline & Leverage & omitted & & & & & \\
\hline & Age & omitted & & & & & \\
\hline & Size & 0,0026 & 0,4000 & 0,6870 & & & \\
\hline & Listing status & 0,0101 & 0,6400 & 0,5260 & & & \\
\hline \multirow[t]{6}{*}{ B } & Return & 0,0108 & 1,2700 & 0,2060 & 0,0596 & 2,5700 & $0,0429 * *$ \\
\hline & Earnings & $-0,0126$ & $-0,8300$ & 0,4080 & & & \\
\hline & Leverage & omitted & & & & & \\
\hline & Age & 0,1393 & 2,3300 & $0,0220 * *$ & & & \\
\hline & Size & omitted & & & & & \\
\hline & Listing status & 0,0116 & 0,9800 & 0,3290 & & & \\
\hline \multirow[t]{6}{*}{$\mathrm{C}$} & Return & 0,0153 & 1,7500 & $0,0830^{*}$ & 0,0794 & 3,1300 & $0,0181 * *$ \\
\hline & Earnings & $-0,0121$ & $-0,8100$ & 0,4210 & & & \\
\hline & Leverage & 0,0662 & 1,7400 & $0,0850^{*}$ & & & \\
\hline & Age & 0,1393 & 2,3300 & $0,0220 * *$ & & & \\
\hline & Size & omitted & & & & & \\
\hline & Listing status & omitted & & & & & \\
\hline
\end{tabular}

Notes: * Significant at $\mathrm{p}<0.1 ; *$ Significant at $\mathrm{p}<0.05$.

\section{Conclusion, Limitations and Recommendations}

This study empirically investigated the association between mandatory disclosure and company value, expressed by the share price anticipation of earnings, as well as, other factors that influence mandatory disclosure practice. The analysis revealed that, on average, the sample companies disclose information for the $91.51 \%$ of items required, indicating high compliance with the mandatory rules. This means that listed companies in UK place a lot of emphasis on the IFRSs disclosures, namely, the IASB help companies to become aware of the consequences of non-disclosure of adequate information in their annual reports. Moreover, the overall compliance with mandatory disclosure by UK companies is high compared to the companies of other countries. The study also revealed that companies gradually increased their level of disclosure since 2006, indicating that companies gradually develop their reporting practice and become more experienced in providing financial information for investors and other market participants.

A significant association, at 0.10 level, was detected between company value and the extent of mandatory disclosure that is consistent with previous research. Additionally, it was found that leverage and age are significantly correlated with mandatory disclosure, while other company characteristics, such as earnings, size and listing status are not. These results are also consistent with previous researches. The findings support the regulation theory, which argues that regulation is a significant positive factor of the level of disclosure; therefore disclosure should not rely solely on the market mechanism. Consequently, managers should take all the necessary measures to ensure that all mandatory information items are adequately disclosed in the annual report in order to avoid penalties and therefore, obtain benefits for their company (i.e. lower cost of capital, high stock liquidity, etc).

However, there are some limitations in this study, thus the results should be treated with caution. First of all, the number of observations is quite limited due to the fact that the necessary data are not in a digital form and they were manually collected. Moreover the sample consisted of companies included in the FTSE 350 Index of London Stock Market, which determines the level and quality of the financial reporting, the accuracy of forecasts about the future value of companies and the transparency. These companies have internal incentives to ensure high quality of disclosure in order to meet the expectations of investors. Second, the disclosure index scoring and the interpretation of results inevitably suffer from subjectivity, due to the nature of the research topic. Third, the IFRSs are constantly updated by IASB: new amendments, revisions of old standards and issuance of new standards. Therefore, the construction of disclosure index should also be updated respectively. Finally, while statistical analysis helps to determine the nature and the magnitude of the impact of the significant corporate attributes on mandatory disclosure, it cannot reveal the underlying reasons of this relationship.

Notwithstanding the above limitations, the results are sufficiently interesting to justify an extension of such a 
research to a larger sample size and to other economies. Furthermore, future research could incorporate corporate governance issues that have become more significant in recent years, such as whether board composition affects disclosure practice or whether the relationships between management, board of directors, other shareholders impact on the extent of disclosure. Moreover, since particular industries and financial companies were excluded from the sample of this study, future research could be extended by the inclusion of these industries.

\section{References}

Adina, P., \& Ion, P. (2008). Aspects regarding corporate mandatory and voluntary disclosure. Annals of the University of Oradea: Economic Science, 3(1), 1407-1411.

Admati, A. R., \& Pfleiderer, P. (2000). Forcing firms to talk: financial disclosure regulation and externalities. The Review of Financial Studies, 13, 479-519. http://dx.doi.org/10.1093/rfs/13.3.479

Ahmed, K., \& Nicholls, D. (1994). The impact of non-financial company characteristics on mandatory compliance in developing countries: The case of Bangladesh. The International Journal of Accounting, 29(1), 60-77.

Akhtaruddin, M. (2005). Corporate disclosure practices in Bangladesh. The International Journal of Accounting, 40, 399-422. http://dx.doi.org/10.1016/j.intacc.2005.09.007

Al-Htaybat, K., \& Napier, C. (2006). A framework for financial disclosure theories. Working paper, School of Management University of Southampton.

Aljifri, K. (2008). Annual report disclosure in a developing country: The case of the UAE. Advances in Accounting, incorporating Advances in International Accounting, 24, 93-100. http://dx.doi.org/10.1016/j.adiac.2008.05.001

Al-Razeen, A., \& Karbhari, Y. (2004). Interaction between compulsory and voluntary disclosure in Saudi Arabian corporate annual reports. Managerial Auditing Journal, 19(3), 351-360. http://dx.doi.org/10.1108/02686900410524364

Barako, D., Hancock, P., \& Izan, H. (2006). Factors influencing voluntary corporate disclosure by Kenyan companies. Corporate Governance: An International Review, 14(2), 107-125. http://dx.doi.org/10.1111/j.1467-8683.2006.00491.x

Barrett, M. E. (1977). The extent of disclosure in annual report of large companies in seven countries. The International Journal of Accounting, 13(2), 1-25.

Belkaoui, A., \& Kahl, A. (1978). Corporate Financial Disclosure in Canada. Research Monograph No. 1 of Canadian Certified General Accountants Association, Vancouver, 1978.

Berk, J., \& DeMarzo, P. (2011). Corporate Finance (2nd ed.). England: Pearson Education Limited.

Beyer, A., Cohen, A. D., Lys, T. Z., \& Walther, B. R. (2010). The financial reporting environment: Review of the recent literature. Journal of Accounting and Economics, 50, 296-343. http://dx.doi.org/10.1016/j.jacceco.2010.10.003

Bruslerie, H., \& Gabteni, H. (2010). Voluntary financial disclosure, introduction of IFRS and the setting of a communication policy: An empirical test on SBF French firms using a publication score. Multinational Financial Society, Barcelona: Espagne.

Buzby, S. L. (1974). Selected items of information and their disclosure in annual reports. Accounting Review, 49(3), 423-435.

Cerf, A. R. (1961). Corporate reporting and investment decisions. Berkeley: The University of California Press.

Choi, F. D. S. (1973). Financial disclosure and entry to European Markets. Journal of Accounting Research, 11, 159-179. http://dx.doi.org/10.2307/2490187

Chow, C. W., \& Wong-Boren, A. (1987). Voluntary financial disclosure by Mexican corporation. The Accounting Review, 62(3), 533-541.

Cooke, T. E. (1989). Disclosure in the corporate annual reports of Swedish companies. Accounting and Business Research, 19(74), 113-124. http://dx.doi.org/10.1080/00014788.1989.9728841

Copeland, R. M., \& Fredericks, M. (1968). Extent of Disclosure. Journal of Accounting Research, 6(1), 106-113. http://dx.doi.org/10.2307/2490127

Core, J. (2001). A Review of the Empirical Disclosure Literature: Discussion. Journal of Accounting and 
Economics, 31, 441-456. http://dx.doi.org/10.1016/S0165-4101(01)00036-2

Courtis, J. K. (1979). Annual Report Disclosure in New Zealand: Analysis of Selected Corporate Attributes. Research Study No. 8, University of New England, Armidale.

Damodaran, A. (2009). The Dark Side of Valuation, 2nd Edition: Valuing Young, Distressed, and Complex Businesses. Retrieved from http://people.stern.nyu.edu/adamodar/pdfiles/DSV2/Ch11.pdf

Darrough, M. N. (1993). Disclosure policy and competition: Cournot vs. Bertrand. The Accounting Review, 68(3), 534-561.

Dye, R. A., \& Sunder, S. S. (2001). Why not allow FASB and IASB standards to compete in the U.S.? Accounting Horizons, 15, 257-271.

Dye, R. A. (1985). Strategic accounting choice and the effect of alternative financial reporting requirements. Journal of Accounting Research, 23(2), 544-574. http://dx.doi.org/10.2307/2490826

Dye, R. A. (1986). Proprietary and nonproprietary disclosures. The Journal of Business, 59(2), 331-366. http://dx.doi.org/10.1086/296331

Dye, R. A., \& Sridhar, S. S. (2008). A positive theory of flexibility in accounting standards. Journal of Accounting and Economics, 46, 312-333. http://dx.doi.org/10.1016/j.jacceco.2008.09.002

Easterbrook, F., \& Fischel, D. (1991). The Economic Structure of Corporate Law. Cambridge, MA: Harvard University Press.

Einhorn, E. (2005). The nature of the interaction between mandatory and voluntary disclosures. Journal of Accounting Research, 43(4), 593-621. http://dx.doi.org/10.1111/j.1475-679X.2005.00183.x

Entwistle, G. M. (1997). Managing disclosure: The case of research and development in knowledge-based firms. (PhD Thesis). The University of Western Ontario, Canada.

Graham, J. R., Harvey, C. R., \& Rajgopal, S. (2005). The economic implications of corporate financial reporting. Journal of Accounting and Economics, 40, 3-73. http://dx.doi.org/10.1016/j.jacceco.2005.01.002

Gray, S. J., \& Vint, H. M. (1995). The impact of culture on accounting disclosures: some international evidence. Asia-Pacific Journal of Accounting, 21, 33-43. http://dx.doi.org/10.1080/10293574.1995.10510476

Haniffa, R. M., \& Cooke, T. E. (2002). Culture, corporate governance and disclosure in Malaysian corporations. Abacus, 38(3), 317-349. http://dx.doi.org/10.1111/1467-6281.00112

Healy, P. M., \& Palepu, K. G. (2001). Information asymmetry, corporate disclosure, and the capital markets: A review of the empirical disclosure literature. Journal of Accounting and Economics, 31, 405-440. http://dx.doi.org/10.1016/S0165-4101(01)00018-0

Healy, P. M., Hutton, A. P., \& Palepu, K. G. (1999). Stock performance and intermediation changes surrounding sustained increases in disclosure. Contemporary Accounting Research, Fall, 485-520. http://dx.doi.org/10.1111/j.1911-3846.1999.tb00592.x

Hossain, M., \& Hammami, H. (2009). Voluntary disclosure in the annual reports of an emerging country: the case of Qatar. Advances in Accounting, incorporating Advances in International Accounting, 25, 255-265. http://dx.doi.org/10.1016/j.adiac.2009.08.002

Hossain, M., Tan, L. M., \& Adams, M. (1994). Voluntary disclosure in an emerging capital market: Some empirical evidence from companies listed on the Kuala Lumpur stock exchange. International Journal of Accounting, 29(4), 334-351.

Hussainey, K., \& Walker, M. (2009). The effects of voluntary disclosure and dividend propensity on prices leading earnings. Accounting and Business Research, 39(1), 37-55. http://dx.doi.org/10.1080/00014788.2009.9663348

Hussainey, K., Schleicher, T., \& Walker, M. (2003). Undertaking large-scale disclosure studies when AIMR-FAF ratings are not available: the case of prices leading earnings. Accounting and Business Research, 33(4), 275-294. http://dx.doi.org/10.1080/00014788.2003.9729654

Iatridis, G. (2008). Accounting disclosure and firms' financial attributes: Evidence from the UK stock market. International Review of Financial Analysis, 17, 219-241. http://dx.doi.org/10.1016/j.irfa.2006.05.003

Inchausti, B. G. (1997). The influence of company characteristics and accounting regulations on information disclosed by Spanish firms. The European Accounting Review, 1(1), 45-68. 
http://dx.doi.org/10.1080/096381897336863

International Accounting Standard 1. (2010). Presentation of Financial Statements. Retrieved from http://eifrs.iasb.org/eifrs/bnstandards/en/ias1.pdf

International Financial Reporting Standard 1. (2012). First-time Adoption of International Financial Reporting Standards. Retrieved from http://eifrs.ifrs.org/eifrs/bnstandards/en/2012/ifrs1.pdf

International Financial Reporting Standard 8. (2012). Operating Segments. Retrieved from http://eifrs.ifrs.org/eifrs/bnstandards/en/2012/ifrs8.pdf

Kanodia, C., Mukherji, A., Sapra, H., \& Venugopalan, R. (2000). Hedge disclosures, future prices and production distortions. Journal of Accounting Research, 38, 53-82. http://dx.doi.org/10.2307/2672908

Karim, A. K. M. W., \& Ahmed, J. U. (2005). Determinants of IAS disclosure compliance in emerging economies: Evidence from exchange-listed companies in Bangladesh. Working Paper, no. 21, Victoria University of Wellington.

Lang, M. H., \& Lundholm, R. J. (1993). Cross-sectional Determinants of Analysts Ratings of Corporate Disclosure. Journal of Accounting Research, 31(2), 246-71.

Lau, A. (1992). Voluntary Financial Disclosure by Hong Kong Listed Companies. Hong Kong Manager, May/June, 10-19.

Leuz, C., \& Wysocki, P. (2008). Economic consequences of financial reporting and disclosure regulation: a review and suggestion for future research. Working Paper. http://dx.doi.org/10.2139/ssrn.1105398

Lobo, G. J., \& Zhou, J. (2001). Disclosure quality and earnings management. Paper presented at the 2001 Asia-Pacific Journal of Accounting and Economics Symposium in Hong Kong.

Mahoney, P. G. (1995). Mandatory disclosure as a solution to agency problems. University of Chicago Law Review, 62, 1047-1112. http://dx.doi.org/10.2307/1600055

Marston, C. L., \& Shrives, P. J. (1991). The use of disclosure indices in accounting research: A review article. The British Accounting Review, 23, 195-210. http://dx.doi.org/10.1016/0890-8389(91)90080-L

McKinnon, J. L., \& Dalimunthe, L. (1993). Voluntary disclosure of segment information by Australian diversified companies. Accounting and Finance, 33(1), 33-50. http://dx.doi.org/10.1111/j.1467-629X.1993.tb00192.x

McNally, G. M., Lee, H. E., \& Hasseldine, R. (1982). Corporate Financial Reporting in New Zealand: An analysis of User Preferences, Corporate Characteristics and Disclosure Practices for Discretionary Information. Accounting and Business Research, 13, 11-20. http://dx.doi.org/10.1080/00014788.1982.9729725

Nagar, V., Nanda, D., \& Wysocki, P. (2003). Discretionary Disclosure and Stock-Based Incentives. Journal of Accounting and Economics, 34, 283-309. http://dx.doi.org/10.1016/S0165-4101(02)00075-7

Naser, K., \& Nuseibeh, R. (2003). Quality of financial reporting: Evidence from the listed Saudi no financial

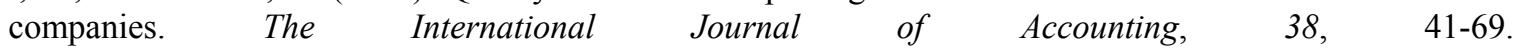
http://dx.doi.org/10.1016/S0020-7063(03)00002-5

Omar, B., \& Simon, J. (2011). Corporate aggregate disclosure practice in Jordan. Advances in Accounting, incorporating Advances in International Accounting, 27, 166-186. http://dx.doi.org/10.1016/j.adiac.2011.05.002

Owusu-Ansah, S. (1998). The impact of corporate attributes on the extent of mandatory disclosure and reporting by the listing companies in Zimbabwe. International Journal of Accounting, 33(5), 605-631. http://dx.doi.org/10.1016/S0020-7063(98)90015-2

Robbins, W. A., \& Austin, K. R. (1986). Disclosure Quality in Government Financial Reports: An Assessment of the Appropriateness of a Compound Measure. Journal of Accounting Research, 24(2), 412-421.

Singhvi, S. S. (1968). Characteristics and Implications of Inadequate Disclosure: A Case Study of India. The International Journal of Accounting Education and Research, 3(2), 29-43.

Singhvi, S. S., \& Desai, H. B. (1971). An Empirical Analysis of the Quality of Corporate Financial Disclosure. The Accounting Review, 46(1), 120-138.

Spero, L. L. (1979). The extent and causes of voluntary disclosure of financial information in three European 
capital markets: An exploratory study. (Unpublished Ph.D. dissertation). Harvard University, USA.

Taplin, R., Tower, G., \& Hancock, P. (2002). Disclosure (discernibility) and compliance of accounting policies: Asia-Pacific evidence. Accounting Forum, 26(2), 172-190. http://dx.doi.org/10.1111/1467-6303.00085

The Conceptual Framework for Financial Reporting. (2012). Retrieved from http://eifrs.ifrs.org/eifrs/bnstandards/en/2012/framework.pdf

Wallace, R. S. O., \& Naser, K. (1995). Firm-specific determinants of comprehensiveness of mandatory disclosure in the corporate annual reports of firms on the stock exchange of Hong Kong. Journal of Accounting and Public Policy, 14, 311-368.

Wallace, R. S. O., Naser, K., \& Mora, A. (1994). The relationship between the comprehensiveness of corporate annual reports and firm characteristics in Spain. Accounting and Business Research, 25(97), 41-53. http://dx.doi.org/10.1016/0278-4254(95)00042-9

Watts, R., \& Zimmerman, J. (1986). Positive Accounting Theory. Englewood Cliffs, NJ: Prentice-Hall.

Yu, J. (2011). The interaction of voluntary and mandatory disclosures: Evidence from the SEC's elimination of the IFRS-U.S. GAAP Reconciliation. Working Paper, Nanyang Technological University (Singapore). 